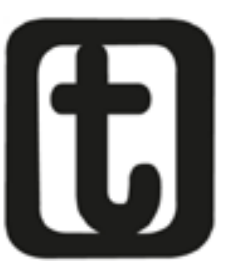

\title{
SERVIÇO SOCIAL, TRABALHADORES E PROLETARIADO: DOS “PRÁTICOS" E DOS "TEÓRICOS"
}

Social service, workers and proletariat: of the "pragmatic" and "theorists" Sérgio Lessa ${ }^{2}$

\section{RESUMO}

O artigo procura argumentar como a distância entre a teoria e a prática profissionais tem sua raiz na incapacidade de a concepção democrática desvelar a essência do mundo em que vivemos. Esta é a origem de uma prática que não tem na teoria sua referência e de uma teoria que não pode incidir sobre a realidade da prática profissional.

\section{PALAVRAS-CHAVE}

Teoria e prática. Concepção democrática. Revolução.

\section{ABSTRACT}

This article argues that the distance between professional theory and practice is grounded in the incapacity of the democratic conception to reveal the essence of the world we live in. This is the origin of a practice that has no theory as reference, and a theory that cannot be applied to the reality of professional practice.

${ }^{1}$ Um agradecimento especial é devido aos pareceristas. As indicações foram muito úteis.

${ }^{2}$ Professor do Departamento de Filosofia da Ufal e membro do Comitê Editorial da Crítica Marxista. E-mail: <sergio.lessa.ontologia@gmail.com>. 


\section{KEYWORDS}

Theory and practice. Democratic conception. Revolution.

\section{INTRODUÇÃO}

Retornar à sala de aula como aluno de graduação - tendo já várias décadas de experiência como docente e com idade para ser avô da maior parte dos meus colegas -, propiciou uma interessante experiência, uma rica vivência com os alunos e com a formação profissional. Este é o primeiro de três artigos voltados à sistematização desta experiência e será dedicado a um aspecto do problema que, aos graduandos em Serviço Social, não raramente comparece como um choque entre os teóricos e os práticos na profissão.

Sendo muito breve, a relação entre a categoria trabalho e a profissão transborda os limites de uma questão ontológica da maior importância. Articula-se com uma dada concepção, mais propriamente democrática que comunista, das tarefas da revolução e do conteúdo da emancipação humana. É neste contexto que a substituição do proletariado pelas imprecisas noções de trabalhadores ou de classe-que-vive-do-trabalho exibe todo o seu potencial ideológico. Tal substituição, para sumariar uma questão das mais complexas e plena de ramificações, é decisiva para velar a distinção entre reforma e revolução, entre o projeto socialdemocrata de um capitalismo de face humana e o comunismo. Para o Serviço Social, especificamente, a dissolução do proletariado no conjunto dos assalariados faz ainda parte de uma concepção simplista, dualista, da sociedade burguesa, segundo a qual viveríamos em uma sociedade cuja contradição fundamental se situaria entre o conjunto homogêneo dos trabalhadores e a burguesia.

Uma das consequências da incapacidade de compreender o complexo processo de reprodução do capital por parte desta concepção simplista da sociedade é o abismo que se desenvolveu entre os objetivos estratégicos do nosso código de ética e a prática profissional. Para o agir profissional, a teoria emancipadora não serve; para 
emancipar o mundo, a prática profissional não tem muita serventia. $\mathrm{Na}$ categoria, aprofunda-se a distância entre os teóricos (cuja base social tem seu centro na academia) e o conjunto dos profissionais cujo universo é a prática. Não é mero acaso que nossos congressos vão se tornando tão caros que apenas a parcela mais rica da profissão pode deles participar. Perdidas mediações históricas decisivas como o sujeito revolucionário, a superação do sistema do capital (Mészáros) perde qualquer potencial orientador da prática; a prática, por sua vez, nestas circunstâncias, pouco pode fazer além de converter as suas necessidades em suas virtudes. Este é o fundamento último do que, aos graduandos, comparece como um desencontro entre os teóricos e os práticos. Em alguma dimensão, é preciso reconhecer, os graduandos têm lá sua razão.

Talvez seja um exagero aceitável para um artigo a afirmação de que a história da profissão nas últimas três ou quatro décadas incorporou o que de mais valoroso, humanamente generoso, compareceu da luta contra a ditadura. Não seria menos verdadeiro reconhecer, ainda, que nesse período o movimento interno à profissão (a "[...] reconceituação com intenção de ruptura [...]", o "[...] Método BH [...]", o Congresso de 1979, a participação na Constituinte de 19871988 etc.) também incorporou uma concepção dualista da sociedade. Segundo esta concepção, a sociedade burguesa seria composta por dois grandes e homogêneos blocos, a burguesia versus os trabalhadores. Segundo José Paulo Netto (1990), na

[...] noção de 'classe oprimida' [do Método BH, o momento fundante da "intenção de ruptura"] compreendem-se dois simplismos - um teórico, outro crítico analítico. Ela, noção basicamente política (que, no entanto, parece recobrir determinações econômicas: os explorados estão subsumidos nos oprimidos), sugere a remissão a uma estrutura social paradigmaticamente dicotômica, o que compromete à partida não apenas o seu potencial para a intervenção, mas sobretudo sua capacidade de decifrar o real (NETTO, 1990, p. 279-80).

José Paulo menciona na sequência do texto, em duas notas, como tal concepção dicotômica lançou raízes na produção do Serviço So- 
cial nos anos seguintes à experiência do Método BH (NETTO, 1990, p. 279, nota 357) e, ainda, como na "[...] revisão autocrítica [...]" que seus membros fizeram há o reconhecimento de que o perfil das "[...] classes trabalhadoras [...]", enquanto classe, “[...] não se configura como um todo homogêneo [...]" (NETTO, 1990, p. 280, nota 358). Aponta ainda, com precisão, a relação entre essa concepção de sociedade burguesa e o “[...] marxismo sem Marx [...]” que marcou muito das reflexões da profissão naquele momento histórico. E, como se não bastasse, José Paulo sinaliza como tal concepção de sociedade, por não ser capaz de pensar o mundo real, também não possui condições de orientar a prática transformadora que seus autores pretendiam.

A heterogeneidade no interior das classes trabalhadoras à qual a revisão autocrítica alude é justamente a distinção ontológica entre o proletariado e os demais assalariados. José Paulo tem toda razão: sem a delimitação das distintas funções sociais presentes sob a relação genérica do emprego assalariado (LESSA, 2007), não há qualquer possibilidade de desvelamento da reprodução do capital em uma teoria que oriente uma prática profissional consequente (LESSA, 2007a). A raiz da impossibilidade de se superar o quase autismo entre nossa prática e nossa teoria está na incapacidade de ultrapassar tal concepção dicotômica e simplista, estruturalista antes que marxista, da sociedade.

\section{ABAIXO A DITADURA!}

A visão de mundo que, dicotômica e simploriamente, compreende a sociedade contemporânea como uma luta entre os trabalhadores e a burguesia, entre dois blocos homogêneos e imediatamente antagônicos, se relaciona ao desenvolvimento dos movimentos populares dos anos de $1980^{3}$.

Nos anos de 1970, a aproximação da crise estrutural do capital, como resultado de certo "[...] desenvolvimento desigual e combi-

\footnotetext{
3 "“[... ] as bases sociopolíticas da perspectiva da intenção de ruptura estavam contidas e postas na democratização e no movimento das classes exploradas e subalternas derrotadas em abril" (NETTO, 1990, p. 257).
} 
nado [...]", fez do Brasil um paraíso das multinacionais e passamos por um processo de crescimento econômico e modernização industrial. Enquanto a economia mundial dava seus primeiros passos na crise, o Brasil se desenvolvia e apenas na segunda metade dos anos de 1970 a crise se instalaria entre nós. Nenhuma surpresa: a riqueza concentrou-se predominantemente no grande capital e, secundariamente, na classe média. Massas novas de trabalhadores urbanos foram geradas pelo êxodo rural e a industrialização subordinada (Ianni, 1994) foi acompanhada por uma concentração sem paralelo da propriedade da terra, mais uma das determinações do nosso passado colonial ${ }^{4}$. Na periferia das grandes cidades, concentrou-se uma massa de trabalhadores cujos salários conheceram o menor poder aquisitivo desde os anos Vargas (o valor real mais baixo do salário mínimo ocorreu em 1975).

Além disso, no mesmo ano de 1978 em que André Gorz anunciava o fim da classe operária como o sujeito revolucionário em seu Adeus ao proletariado, as greves no $\mathrm{ABC}$ colocavam o setor mais especializado e melhor pago do proletariado industrial surgido do Milagre no centro do cenário político. Entre nós, as teses acerca do “[...] fim do proletariado [...]”, que já tinham espaço nas teorias acerca dos "novos sujeitos históricos" (SADER, 1995), teriam que esperar alguns anos para que se generalizassem.

Com a massa de trabalhadores miseráveis dos centros urbanos, com a derrota da estratégia de luta armada no campo e na cidade, com o bloqueio da via institucional pela ditadura, com a repressão e a desestruturação das organizações de esquerda - e, no cenário mundial, com a crise da URSS e com o avanço das lutas camponesas de libertação nacional -, deu-se uma curiosa e inesperada convergência. Alguns movimentos espontâneos de reivindicação da periferia de São Paulo, a esquerda católica representada pelas Comunidades Eclesiais de Base e o que restara do PC do B paulista, Polop e outras organizações revolucionárias convergiram em um movimento molecular e reivindicatório local que evoluiu para uma

\footnotetext{
${ }^{4}$ Chasin é um autor importante das tentativas de investigar até que ponto o desenvolvimento do capitalismo em nosso país se distingue tanto da "[...] via prussiana [...]" quanto do desenvolvimento capitalista típico dos países centrais, consubstanciando uma trajetória histórica particular, peculiar, que denominou de "[...] via colonial [...]" (CHASIN, 1978).
} 
reunião de poucas dezenas de moradores na Zona Sul de São Paulo a qual, por sua vez, decidiu por uma Assembleia para mostrar às autoridades que não era possível viver com aquele salário mínimo. Desta assembleia, nasceu a proposta de coleta de assinaturas contra a carestia que se converteria no Movimento do Custo de Vida. Entre os anos de 1974 e 1978 (ano das greves no ABC) o movimento foi se expandindo, de início lentamente e, nos meses finais, de forma quase explosiva para os padrões da época, em mais de um miIhão de assinaturas - coletadas muitas vezes em mutirões públicos no centro de São Paulo -, que foram reunidas na Catedral da Sé na maior manifestação (cinco mil pessoas) contra a carestia antes das greves do $A B C$. Entre os cinco mil do Movimento Contra o Custo de Vida, na Praça da Sé, e os 100 mil do $1^{\circ}$ de maio de 1980 na Vila Euclides, foram apenas 2 anos!

Esta experiência marcou profundamente os seus militantes. Possibilitou uma forma de luta e organização que a ditadura tinha dificuldades em reprimir. Difusa em centenas de bairros, sem um núcleo dirigente que pudesse ser identificado, com uma base popular que tendia a crescer a cada vitória (um asfalto aqui, uma escola ali, um centro de saúde acolá etc.), esta era uma forma de luta que possibilitava tanto a sobrevivência individual dos militantes como a reorganização dos partidos revolucionários. Ao mesmo tempo, as tentativas de elevar o movimento reivindicatório à luta diretamente política, mesmo quando rompiam com o foquismo, como foi o caso do MEP, redundavam em prisões e no desmantelamento do pouco acumulado. Naquele momento5, a combinação da luta legal com a luta clandestina na organização e fortalecimento dos movimentos reivindicatórios possibilitou um acúmulo real, efetivo - e de enorme importância frente às derrotas tanto da luta armada quanto da estratégia de transição pelo alto do $\mathrm{PCB}^{6}$.

\footnotetext{
${ }^{5}$ Talvez a melhor análise feita naqueles tempos tenha sido a Plataforma para a União dos Comunistas, de 1975. Sua proposta de articulação entre a luta legal e clandestina era uma significativa e importante ruptura com as teses foquistas e com as que propunham um enfrentamento mais radical com a ditadura.

${ }^{6}$ A relação do PCB com os movimentos populares foi, para se dizer o mínimo, ambígua. Desconfiava de um movimento que não tinha possibilidade de controlar (sua implantação na periferia era irrisória) e cuja base social estava distante das suas ligações com o sindicalismo pelego e com os setores de classe média. Não sem alguma razão, apontava o obreirismo, o basismo e o espontaneísmo dos movimentos; utilizava, contudo, tais argumentos como pretexto para se manter afastado. Sua estra-
} 
A concepção de revolução que se gestava nos movimentos populares postulava que organizaríamos massas cada vez mais amplas da população da periferia para a luta, a qual elevaria a consciência economicista à revolucionária, numa concepção leninista muito mal assimilada. Organização cada vez mais ampla corresponderia à consciência cada vez mais avançada; consciência cada vez mais avançada, por sua vez, significaria a participação cada vez mais intensa e numerosa do povo na política, desalojando a burguesia este o germe da Nova Democracia (Mao-Tse-Tung). Da Nova Democracia para o socialismo, seria apenas um passo.

Com clara intenção socialista, com um conteúdo anticapitalista professado, não é uma inteira falsidade afirmar que a concepção revolucionária que predominava no movimento popular era democrática e politicista (Chasin, 1977). Democrática, por conceber que o socialismo viria pelo aprofundamento da participação democrática das massas. Os mecanismos da democracia burguesa (eleições, parlamentos, liberdade de imprensa, de organização, direitos sociais etc.) eram tidos por formas germinais da democracia socialista e, por isso, seu aprofundamento e radicalização conduziriam ao socialismo. Politicista porque a transição tinha um caráter quase que exclusivamente político, como se a política e não o trabalho fosse o fundante da sociabilidade. A estatização dos meios de produção e o planejamento econômico centralizado eram identificados à superação do capital. Ignorávamos que sem a transição do trabalho proletário ao trabalho associado não há transição política possível ao socialismo.

Tal profunda ignorância resultava de três tendências históricas. A primeira, da degenerescência teórica do próprio movimento comunista internacional desde pelo menos os anos de 1920, como argumentou Fernando Claudin no seu clássico A crise do movimento comunista (CLAUDIN, 1970). A cada geração assistimos à consistente e sistemática reprodução ampliada da ignorância dos militantes e dirigentes. A segunda foi o fato de a repressão dos anos de chumbo ter separado dos jovens militantes os revolucionários mais ex-

tégia de transição para a democracia pelo alto mais sua proximidade cuidadosamente cultivada com os sindicalistas pelegos que classificavam de progressistas, levou-o a se opor às greves de 1978-1979. 
perientes que poderiam ter contribuído para a formação da nova geração7 . E, por fim, a concepção democrática e politicista concebia a teoria como desnecessária. Se a prática estava mostrando no dia a dia o caminho a seguir, que importância poderia ter os milhares de páginas escritas que as pessoas do povo jamais leriam? Que melhor lição para os intelectuais revolucionários que o caminhar a olhos vistos do povo para o socialismo? E algumas citações de Lênin, Mao e Stalin resolviam, finalmente, a questão ${ }^{8}$.

Era essa a concepção de mundo que predominava nos movimentos populares dos anos de 1970-80. O objetivo final era o socialismo, o meio para se alcançar esse objetivo era o aprofundamento da luta democrática contra a ditadura: lutar pela democracia era lutar pelo socialismo. Acreditávamos - defendíamos explicitamente - que a luta pela saúde, pela escola, pelo asfalto, pela terra, contra a carestia etc., eram passos das massas em direção ao socialismo. ${ }^{9}$

O apogeu dos Movimentos Populares foi também o início de seu ocaso: as greves do $A B C$ de $1978-80$. As greves de apenas algumas fábricas (não houve sequer uma greve geral no $A B C$, para não falar de uma greve geral da Grande São Paulo) mudaram o cenário político nacional, desencadearam uma moderada onda grevista por todo o país e, a ditadura, nunca mais se recuperou. A confluência da luta popular com a luta operária parecia indicar o acerto da estratégia política (e, portanto, da concepção teórica e ideológica) do movimento popular: a luta dos bairros foi polarizada e catalisada pelas greves operárias. A simpatia generalizada da população pelos grevistas, os fundos de greve (alimentos e dinheiro), a atuação política dos setores revolucionários da igreja (os partidários

\footnotetext{
7 Há um conjunto de depoimentos úteis para a reconstrução da experiência daqueles anos do ponto de vista dos prisioneiros políticos. A relação que muitos deles relatam com Jacob Gorender é uma amostra do quanto o afastamento forçado da antiga tradição teórica foi prejudicial. Confronte Freire, Almada e Ponce (1997). Pela presença de revolucionários do porte de Marilda lamamoto, José Paulo Netto e Carlos Nelson Coutinho, a trajetória do Serviço Social incorporou alguns elementos que não estavam tão presentes, ou não atuavam com a mesma intensidade, no que foi o horizonte teórico típico dos Movimentos Populares.

${ }^{8}$ Como esta concepção mais geral articulava a teoria revolucionária e a prática dos revolucionários em um praticismo absolutamente avesso à teoria, em que pese o discurso rigorosamente oposto, analisamos em Lessa (1995).

9 É interessante como esta concepção de mundo, este Zeitgeist, se refletiu até mesmo nos intelectuais europeus. As teses de Regis Debray sobre a revolução latino-americana bem com os manuais de Marta Hanecker são, hoje, curiosos testemunhos deste fato.
} 
mais radicais da teologia da libertação) etc. - tudo parecia confirmar o acerto da nossa estratégia. O cerco pela periferia de Manágua da ditadura somozista, em 1979, era tido por prenúncio do que viveríamos. Maior luta, maior organização, consciência mais elevada, Nova Democracia e socialismo: a história estaria confirmando o acerto político e ideológico do movimento popular.

Foi no contexto do apogeu dos movimentos populares e das greves do $A B C$ que tivemos o histórico, porque heroico, Congresso da Virada de 1979. A nova mesa dirigente contou com a presença de Lula, representante do mais popular na luta contra a opressão. O espírito dos movimentos populares se fazia também presente na profissão e o compromisso com os explorados foi afirmado com tal intensidade que marca a nossa história de assistentes sociais até hoje.

\section{A DEMOCRACIA}

Os anos de 1980 reservavam duras surpresas. Consolidou-se a estratégia neoliberal para administrar a crise. Nacionalmente, o capital alcançou um acordo interno para a transferência do poder aos civis (ALMEIDA MELLO, 1989) e o movimento popular sofreu uma enorme derrota nas eleições para a Prefeitura de São Paulo em 1982. Nos bairros mais organizados a vitória foi de Montoro, quando não de Paulo Maluf. A população se afastava e a participação popular foi minguando. É fácil compreender o que ocorria: com a democracia, as massas populares passaram a se iludir com as promessas dos políticos burgueses (Covas, Montoro, Maluf, em São Paulo, por exemplo) que possuíam o poder, que faltava a nós, os revolucionários, para a melhoria dos bairros. Todavia, conseguia-se atrair alguns populares para os comitês eleitorais. Pela mesma ilusão, era agora mais fácil organizar comitês de apoio a candidatos em época de eleição. Por um inesperado desenvolvimento, a atrasada consciência popular, iludida com a política burguesa, confluía com a nossa concepção politicista e democrática e, o que era uma derrota, era fantasiado como o caminhar para frente do povo que evoluía das lutas econômicas para as políticas! A via de menor resistência da estratégia eleitoreira foi se impondo e nada mais natural que, logo a seguir, predominasse entre nós a estratégia de demo- 
cratizar a democracia por dentro da Assembleia Constituinte.

A Constituinte foi o cenário ideal para que a concepção democrática, politicista e eleitoreira começasse sua degenerescência em direção ao "[...] cretinismo parlamentar [...]" que uma boa Constituição faria deste um novo país. Nosso passado colonial, o complexo processo de formação da burguesia brasileira e do seu antagonista histórico, o proletariado - ao lado de outros traços profundos do Brasil contemporâneo - seriam revogados se o movimento popular conseguisse inserir na nova Constituição institutos que favorecessem a participação e a iniciativa democrática das massas. Tudo seria decidido (a nosso favor!) pela eleição de constituintes e, portanto, era necessário disputar com a burguesia o voto das massas. Deveríamos adequar o discurso para conseguir o máximo dos votos - ainda que isso custasse não dizer tudo ao povo. Seria uma mera questão de tática dizer o que o eleitor queria ouvir e se calar sobre questões delicadas (comunismo, aborto, opressão da mulher, revolução, propriedade privada etc.), pois, conquistados os votos, venceríamos na Constituinte: via segura ao socialismo. Deveríamos fazer alianças com políticos burgueses e defendê-los junto ao povo. A propaganda revolucionária (Lenin) cedia rapidamente lugar ao oportunismo eleitoreiro.

A presença do movimento popular na Constituinte foi importante, ainda que não pelas razões que esperávamos. A transição para a democracia consolidou no poder as mesmas forças econômicas que espoliavam "[...] nosso povo e nosso país [...]” (como se dizia à época). Nem as pessoas foram trocadas! Sarney, o último presidente da Arena, foi o primeiro presidente da democracia e é, até hoje, chave na política petista. A transição foi tão moderada que políticos burgueses de estirpe como Ulysses Guimarães, Leonel Brizola e Mário Covas não tiveram a menor oportunidade frente aos serviçais dos militares como Tancredo Neves e Sarney. Uma figura comprometida com as torturas como Romeu Tuma se tornou um ilustre - e moralizador - integrante da República Democrática!

Os movimentos popular e operário entraram nos anos de 1990 em um profundo refluxo. O desemprego explodiu, a desmobilização

${ }^{10}$ Esta é uma expressão de Marx, em 018 Brumário de Luis Bonaparte. 
cresceu na mesma velocidade do sucesso eleitoral das políticas neoliberais, primeiro na esteira do Plano Real de FHC e, depois, na sequência, dos governos Lula. Os operários do $A B C$ vão se convertendo em base eleitoral do neoliberalismo e os avanços na Constituinte sequer resultaram em uma alteração para melhor da nossa tradicional má distribuição da renda, quanto mais na Nova Democracia. O restrito apoio popular obtido para a eleição dos constituintes se esgarçaria ao longo das eleições seguintes. Perdidos a base e o apelo populares, para ser vitoriosa a estratégia eleitoreira precisava se profissionalizar, isto é, tornar-se burguesa não apenas no conteúdo, mas também na forma. E, uma vez mais: o importante era eleger parlamentares para se aprofundar a democracia - mediação segura ao socialismo. O Parlamento vai se convertendo, nessa involução ideológica, no local privilegiado - e, depois, no único local - em que se faz Política (agora, com p maiúsculo)!

No lugar de questionarmos os fundamentos destas tantas e sucessivas derrotas, concluímos, como uma verdade revelada, que não bastaria uma boa Constituição, seria preciso ter vontade política para dar vida a ela! Trocando em miúdos, as vitórias na Constituinte apenas alterariam o país com a eleição de Lula à Presidência. As vitórias de Pirro na Constituinte (o Estatuto da Criança e do Adolescente (Ecriad), o Sistema Único de Saúde (SUS) etc.) se completaram com a derrota de 1989 do PT frente a Collor. Os resquícios de radicalismo da estratégia revolucionária democrática dos anos de 1970 deveriam ser enterrados; um PT profissional e competente era o todo necessário para que o cretinismo parlamentar reinasse inconteste. Esta virada à direita deu certo e, quando Lula chegou à Presidência, uma enorme parcela da esquerda se emocionou como se fosse a vitória, afinal, da estratégia democrática dos anos de 1970. Uma parcela não tão grande aderiu ao poder.

A vitória do PT é a vitória do capital contra o trabalho. Esta é a essência da derrota do projeto revolucionário democrático. A transição para a democracia conduziu a uma forma de controle da burguesia sobre os trabalhadores mais eficiente do que a velha ditadura. Muitos dos revolucionários do passado degeneraram em uma nova burocracia, ilustrada e moderna, alojada no Estado, nos sindicatos (hoje, paraestatais), na imprensa e nas universidades. E, também, na 
direção do que restou do movimento popular, com raras exceções. A derrota da geração dos movimentos populares é também - e essa é uma consequência que em parte poderia ser evitada por uma consciência mais elevada do processo - a degenerescência dos seus indivíduos. Muitos se converteram de "[...] tribunos do povo [...]" (Lenin) em "[...] lacaios do capital [...]" (perdoem a recaída nos anos de 1970). Genoino e Zé Dirceu não, mas não são fenômenos isolados. Sobre isso nem é preciso se estender.

\section{O NOSSO EQUÍVOCO}

Sem teoria revolucionária não há revoluções que possam ser vitoriosas. Contudo, uma consciência revolucionária que se expresse em um bom projeto não garante, por si só, uma revolução. Em poucas palavras, na crítica ao projeto democrático devemos evitar dois equívocos. O primeiro: tomar suas debilidades teórico-ideológicas como causas da não ocorrência da revolução proletária em nosso país. O segundo: considerar as debilidades como pouco importantes, pois com ou sem elas, a revolução não teria ocorrido. Elas não são a causa da não ocorrência da revolução proletária em nosso país (há causas muito mais profundas, mundiais, que se relacionam ao período contrarrevolucionário que predominou nesses anos). No entanto, elas foram significativas: auxiliaram na consolidação da vitória da burguesia pela transição à democracia sem maiores ameaças ao poder do grande capital e, ainda, na domesticação do PT, do movimento sindical e do que restou dos movimentos populares ${ }^{11}$.

A debilidade mais importante da concepção revolucionária democrática que predominou nos movimentos populares é, justamente, o seu caráter democrático. A concepção de que o comunismo é a democracia burguesa levada às suas últimas consequências revela, por si só e desde logo, uma brutal incompreensão do que é a democracia e, no polo oposto, do que é o comunismo.

\footnotetext{
"Em generalizações dessa ordem sempre são cometidas injustiças: o particular não pode receber a devida atenção. Não há aqui espaço para pontuarmos essa observação como seria devido. Há resistências, algumas delas muito significativas, outras com potencialidades que o futuro pode revelar surpreendentes. Isso, contudo, não invalida essa observação mais geral.
} 
A democracia, para a minha geração, era a entrada das massas na luta política; seria antagônica ao capital e mediação acertada ao socialismo. Jamais nos passou pela cabeça que a democracia é exatamente o oposto: é a entrada das massas como trabalhadores assalariados na política burguesa. Tal participação perpetua a condição de assalariamento - isto é, a subordinação do trabalho ao capital. Seu horizonte mais amplo não vai além da luta em direção a "[...] um salário justo por uma jornada justa de trabalho" (MARX, 1978, p. 99). E há uma razão profunda - que não passa nem pela decisão política, nem pela vontade da classe dominante, nem pela consciência dos trabalhadores - para que a democracia não possa ser outra coisa. Referimo-nos aos seus fundamentos últimos (para sermos precisos, ontológicos): ela é a forma mais desenvolvida de organização do poder que brota da forma mais desenvolvida possível da propriedade privada, o capital - ela é a forma mais aperfeiçoada da organização política. ${ }^{12}$

Diferente das sociedades de classes pré-capitalistas, nas quais o Estado e a extração do trabalho excedente mantinham uma relação imediata, no século 19 a exploração do trabalho passará a ser realizada predominantemente com a mediação do mercado (pela extração da mais-valia). Coube às Revoluções Burguesas retirar o Estado da economia e limitar sua ação à manutenção da ordem. Pelas revoluções burguesas o capital realizou sua emancipação do Estado, sua “[...] emancipação política” (MARX, 2009).

Esta é a gênese do Estado contemporâneo. Ele é a propriedade privada burguesa elevada à política; é a expressão na esfera da política da reprodução do capital. Agora, diferente da feudalidade ${ }^{13}$, as

\footnotetext{
${ }^{12} \mathrm{~A}$ descoberta de que a política é o poder centrado no Estado e fundado pela propriedade privada, é de Marx e Engels (MARX, 2010; 2009; 1974; MARX e ENGELS, 2005; ENGELS, 2010). Mészáros (2002), em Para além do capital, sintetizou uma investigação de décadas sobre o Estado contemporâneo na qual essa posição se expressa sempre vigorosamente. José Chasin, um dos mais importantes marxistas da geração passada e cuja obra nem de longe merece a devida atenção (parte, sem dúvida, da crise do pensamento revolucionário), desde os anos de 1970 se manifestava contra o "politicismo" e contra o fetiche da democracia (CHASIN, 1977; 1989). Ivo Tonet contribuiu decisivamente neste sentido - entre outros textos, conferir Tonet (1989; 1999; 2002; 2005; 2009). Das primeiras críticas do jovem Marx à política, ao Estado e à democracia, tratamos em Lessa (2007b).

${ }^{13} \mathrm{Em}$ A questão Judaica e em A ideologia alemã, Marx e Engels empregam a expressão feudalidade para expressar a relação de subordinação do indivíduo à totalidade social peculiar às sociedades de classe pré-capitalistas. Em A miséria da filosofia, o mesmo termo aparece para indicar os modos de produção pré-capitalistas.
} 
mercadorias farão os seus guardiões estabelecerem relações entre si e, então, a vontade dos indivíduos passa a residir nas mercadorias de que são possuidores (MARX, 1983, p. 79 e seguintes). Estamos em plena regência do fetichismo da mercadoria: a criatura envolveu o criador e, então, a identidade do último passou à primeira. O indivíduo burguês é a sua propriedade privada, a sua essênciaa ${ }^{14}$ são as relações mercantis: a sociedade se reduziu a uma arena na qual todos são lobos de todos e o mundo não passa de uma "[...] enorme coleção de mercadorias [...]" (MARX, 1983, p. 45). O lugar dos indivíduos na estrutura produtiva não é, como antes, mediado pelo Estado, mas pelo mercado. Apenas assim as leis do mercado (que nada mais são que as leis da reprodução do capital) podem ter plena vigência. A organização política (o Estado) imprescindível à sociedade capitalista deve aplicar cotidianamente a violência de tal modo a assegurar a plena vigência do mercado; deve garantir uma ordem na qual a concorrência de todos contra todos não apenas seja possível, mas melhor ainda, seja potencializada (MARX, 1983; 1985; 1969, LUKÁCS, 1981, p. 670-672; MÉSZÁROS, 2002; TONET; 1989; 2002; 2005; ENGELS, 2010; LESSA, 2007b).

O poder deixa de ser hereditário para ser objeto de disputa; sua posse corresponderá à correlação de forças entre as diferentes facções dos proprietários privados. $E$ tais facções se manifestam principalmente no e pelo mercado. A disputa pelo poder político, por sua vez, requer que os indivíduos sejam guardiões das mercadorias no preciso sentido de que são livres para se moverem pelas relações mercantis da forma mais apropriada a seus interesses. Os indivíduos são, então, livres - sua liberdade tem por conteúdo as relações sociais que estabelecem voluntariamente buscando o que julgam ser a melhor maneira de reproduzir a propriedade de que são guardiões. É o individualismo burguês em seu máximo grau de alienação ${ }^{15}$ e a sua expressão política é a cidadania.

A liberdade, de que a burguesia é tão ciosa, não passa da liberdade de cada um realizar aquilo que julga melhor negócio para a propriedade privada da qual é guardião. Ser livre, agora, é não ter a

\footnotetext{
${ }^{14}$ A essência humana é o "[...] conjunto das relações sociais [...]" (MARX, 2009a).

${ }^{15}$ No sentido de Entfremdung, a desumanidade socialmente posta.
} 
intervenção do Estado a limitar as possibilidades de ação de cada cidadão no mercado. Até a relação mais íntima das pessoas consigo próprias passa a ser dominada pela mercadoria: uma conta bancária que cresce ou que diminui é parte importante na elevação ou queda do conceito que fazemos de nós próprios. A liberdade burguesa, por isso, deve ser sempre e a cada momento especialmente regrada: ela é a expressão, na esfera dos atos individuais, das relações concorrenciais - as únicas possíveis entre "[...] guardiões de mercadorias [...]" (MARX, 1983, p.79-80). Somos agora, livres lobos dos próprios homens: esse é o conteúdo que a liberdade compatível com a emancipação política tem por limite histórico (MARX, 1983; 1985; 2010; 2009, TONET, 1989; 1999, MÉSZÁROS, 2002, LESSA, 2007b).

Tal como, na esfera econômica, reduz-se o trabalho ao trabalho abstrato, na esfera política abstrai-se o indivíduo concreto no cidadão. A sociabilidade do capital é aquela em que a pessoa real, concreta, plena de mediações, em sua integralidade mais autêntica, simplesmente não tem lugar.

A obra revolucionária da burguesia consistiu em articular o capital, o indivíduo-mônada (o guardião de mercadorias), a forma democrática do Estado e a regência do fetichismo da mercadoria em uma mesma totalidade que é a sociedade burguesa desenvolvida. A democracia é obra histórica da burguesia: a democracia é burguesa ou não tem lugar na história! Não existe a democracia enquanto uma ideia platônica fora da história. A democracia é tão datada quanto o foi o Estado Romano: é fundada pelo trabalho proletário e corresponde, na esfera da política, à generalização por todo o corpo social das relações mercantis. Ela é burguesa - ou não existe. ${ }^{16}$

\footnotetext{
${ }^{16}$ Há uma longa discussão acerca da existência ou não de uma democracia socialista. Nos textos de Marx, Engels e Lenin (dentre os quais, As lutas de classe em França e 018 Brumário de Luís Bonaparte, o Manifesto Comunista, O Estado e a revolução são os mais frequentemente citados) esta expressão comparece, indiscutivelmente. $O$ debate posterior a estes textos, contudo, terminou migrando para um campo tão mais marcadamente liberal (e não apenas na esteira do eurocomunismo), que o conteúdo superador da democracia burguesa pelo socialismo foi sendo paulatinamente substituído por um crescente conteúdo burguês do próprio socialismo. Não levou muito para que as teses de Kautsky no século 19 fossem desenvolvidas até se converterem na concepção de que a democracia burguesa levada à sua radicalidade é o socialismo. Como se o governo do povo, para o povo e pelo povo, de A. Lincoln, pudesse ter qualquer semelhança ou analogia com o adjetivo socialista com que os clássicos caracterizavam a ordem democrática da Ditadura do Proletariado. Com este andar da carruagem, o vocábulo democracia ganhou conotações e hoje provoca ressonâncias ideológicas distintas das de um século atrás. Por esta razão, preferimos salientar o caráter burguês (por insuperável
} 
Esse fundamento ontológico, histórico ${ }^{17}$, da democracia, aliado à impossibilidade da constituição de germes do modo de produção comunista nos interstícios do capital, é o que faz a estratégia democrática uma mediação inviável quando se trata da acumulação de forças para a revolução proletária. O aprofundamento da democracia conduzirá apenas a uma democracia mais profunda, isto é, a uma liberdade ainda maior para o capital explorar o trabalho, a um predomínio ainda mais intenso do fetichismo da mercadoria. O aprofundamento da emancipação política, para recuperar a expressão de Marx em A questão judaica, conduzirá apenas a uma emancipação política mais desenvolvida, jamais conduzirá à emancipação humana (TONET, 1999; 2002; 2005, LESSA, 2007a; 2007b). O aprofundamento da democracia apenas pode fortalecer o poder do capital, nunca o oposto. A democratização da democracia resulta em mais democracia, jamais em comunismo. Por isso, com clarividência, argumenta Mészáros que o único trabalho que pode ter representatividade no Estado é o trabalho abstrato, isto é, aquele reduzido à mercadoria e que faz do seu possuidor a mônada guardiã de mercadoria (MÉSZÁROS, 2002, p.838).

Foi isso que a minha geração de militantes, aquela dos movimentos populares, jamais suspeitou!

Nunca imaginamos que, para superar o capital, deveríamos também superar a democracia. Jamais imaginamos que o comunista é um autêntico, o mais radical, antidemocrata! É preciso superar a sociabilidade cuja reprodução requer a distinção entre sociedade e Estado porque, como vimos, tal distinção é um pressuposto ao livre funcionamento do mercado. Trata-se, sem mais delongas, de conquistar um novo patamar histórico no qual o trabalho proletário seja substituído pelo trabalho associado. Esta substituição

determinação ontológica) da democracia para, então, podermos chamar a atenção de que a ordem socialista, muito mais livre e muito mais liberta, é uma forma superior de organização da sociedade - ainda política, ainda estatal, ainda, portanto, alienada em alguma medida. Esta forma superior é a Ditadura do Proletariado, a qual deverá ser superada pelo comunismo. Para Marx, Engels e Lenin, a Ditadura do Proletariado é o conteúdo do adjetivo socialista na expressão democracia socialista. MeIhor, nos nossos dias, evitar a expressão democracia socialista e empregar, em seu lugar, Ditadura do Proletariado. É, ao menos, uma forma que dificulta a interpretação reformista corrente da expressão democracia socialista, um socialismo com conteúdo democrático, isto é, burguês.

${ }^{17}$ Sobre a relação entre história e ontologia, confronte Lessa (2005). 
colocará no centro da produção as necessidades humanas; o que, por sua vez, requer que todos os humanos participem tanto de sua organização quanto de sua execução. A sociabilidade deixará de ser a livre concorrência entre os indivíduos-mônadas guardiões de mercadorias para se converter na "[...] livre organização dos trabaIhadores associados [...]”. Então, não apenas o Estado, o dinheiro, a política, o Direito e a família monogâmica se tornarão inutilidades históricas e desaparecerão, como também a democracia existirá apenas como lembrança e como evento narrado nos livros de história, tal como são hoje para nós o Estado Romano e o Império Persa.

\section{NOSSOS DESAFIOS}

A debilidade fundamental do projeto revolucionário que predominou nos movimentos populares, retomamos, estava em que desconhecia a essência da sociedade burguesa. Iludimo-nos - graças também a nossa ignorância - que seria a democracia a antessala do socialismo. Fomos joguetes nas mãos da burguesia. Confundimos um projeto democrático com um projeto comunista e nossas ilusões facilitaram a neutralização da força contestadora do movimento operário e popular - quer pela sua conversão em extensão do Estado (como ocorre com as ONGs, com o Orçamento Participativo, com a abertura da direção dos fundos de pensão aos burocratas sindicais, com a cooptação dos sindicatos e dos movimentos populares, etc.), quer pela atuação de forças políticas predominantemente polarizadas pelo PT e pela CUT. A cooptação pela ideologia e pelo Estado burgueses do movimento operário e popular promove, ainda hoje, também a degenerescência das pessoas. As ilusões com a democracia facilitaram em muito a conversão dos antigos combatentes pelo socialismo em modernos burocratas estatais. Sempre há exceções, mas é impressionante a intensidade e a extensão da conversão dos antigos revolucionários em modernos administradores a serviço do capital.

O Serviço Social incorporou o mais generoso da luta contra a ditadura, dizíamos. O compromisso da profissão com a emancipação humana é um marco e um passo da maior importância. Possibili- 
tou avanços inéditos ao Serviço Social, não apenas em se tratando da produção do conhecimento, mas, também, lhe conferindo uma identidade político-ideológica que é notável e única entre as profissões. Ao lado desses e de outros ganhos que não devem nem podem ser menosprezados, nossa profissão também compartilha dos impasses de toda a esquerda que se orienta pela concepção democrática, eleitoreira e politicista.

Do ponto vista político, a concepção democrática que é hegemônica na profissão nos desarmou para a luta. Nosso poder de crítica ao neoliberalismo ficou amortecido, nossa relação com os governos neoliberais em tempos petistas em nada lembra a oposição que fazíamos ao neoliberalismo na era FHC - momento em que nossa combatividade já não era mais a mesma dos anos de 1970. Passamos mesmo a ter representantes históricos da profissão a serviço dos petistas em circunstâncias que seriam impensáveis no passado. A concepção democrática e politicista nos lançou em uma semiparalisia política e nos tem incapacitado a enfrentar o neoliberalismo pela sua totalidade. Sequer para um objetivo tão limitado como confrontar a fase petista do neoliberalismo, a concepção democrática não pode orientar a prática profissional.

Superar as debilidades de tal concepção estratégico-profissional requer uma revisão completa dos nossos fundamentos. É preciso reavaliar nossa relação com o Estado, reavaliar a forma como nos organizamos profissionalmente, repensar nossa forma de ação profissional de tal modo a romper o isolamento em que cada assistente social atua. É preciso, ainda, abrir os congressos e encontros nacionais à categoria profissional, retirando-os, já e agora, da sanha de lucros das empresas de turismo. Afastar a maior parte dos assistentes sociais das instâncias dirigentes da profissão nos enfraquece e nos debilita ideológica e politicamente. O preço será elevado e não em um futuro distante.

Uma reavaliação crítica e profunda de nossos pressupostos e das nossas crenças requer que se traga para o horizonte profissional um projeto revolucionário superador das debilidades e das ilusões democráticas: é preciso colocar não a democratização do Estado e a distribuição de renda, mas sim a superação do Estado, da pro- 
priedade privada e da exploração do homem pelo homem como eixos articuladores tanto da crítica do passado quanto de um projeto futuro. E, para tanto, é preciso superar a concepção dicotômica, simplista e mecanicista que concebe a sociedade como composta por dois blocos antagônicos, os trabalhadores (que seriam todos os assalariados) e a burguesia (os proprietários do capital). É preciso que a profissão recupere a concepção marxiana de que entre os trabalhadores há uma classe especial que, ao produzir todo o "[...] conteúdo material da riqueza social” (MARX, 1983, p. 46), é a única que pode ser a portadora histórica do projeto comunista: a classe operária.

Repensar nosso passado, fazendo a crítica radical e superadora de seus equívocos, implica hoje o reconhecimento do proletariado como o sujeito revolucionário - e o reconhecimento da superação da propriedade privada, do Estado e da família monogâmica como a mediação para a sociedade emancipada, sem classes, que profissionalmente defendemos.

\section{DA PRÁTICA À TEORIA}

Dizíamos, no início, que voltar a ser um graduando depois de tantos anos como professor possibilitou uma melhor compreensão da dicotomia entre os práticos e os teóricos. Ela, ao fim e ao cabo, apenas na aparência é uma dicotomia. Os práticos e os teóricos são, cada um a seu modo, igualmente democráticos.

Os teóricos apresentam aos práticos um projeto de emancipação humana historicamente inviável. Imaginam que com um aumento dos salários teríamos uma menor exploração do homem pelo homem. Levado adiante com persistência e vontade política, este projeto nos conduziria à sociedade emancipada. Aqui cabe a pergunta: emancipada de quê? Pois a exploração do homem pelo homem não está no valor do salário ou na taxa de extração da mais-valia - mas na própria existência do salário. Uma sociedade emancipada dos baixos salários não é uma sociedade "[...] emancipada do capital [...]”. Por isso Marx, em Salário, preço e lucro, termina afirmando 
que “[...] em vez do lema conservador: 'um salário justo por uma jornada de trabalho justa!', [a classe operária] deverá inscrever na sua bandeira esta divisa revolucionária: 'Abolição do sistema do trabalho assalariado!”' (MARX, 1977, p. 377-378).

O projeto democrático pode, corretamente, se autodenominar de ético-político. Acabar com os baixos salários é seu projeto socialista, como tudo que é socialista seria também ético; como tal projeto será implementado pelo Estado, o que necessitamos é de um Estado e de uma política éticos.

A única orientação prática possível a esta concepção é postular a neutralidade de classe do Estado, que poderia ser empregado de modo ético (para distribuir) ou aético (para concentrar renda) e, conclusão decorrente, a necessidade de tomá-lo por dentro. Daí seu politicismo e sua concepção cidadã-eleitoreira. Como no dia a dia os práticos se defrontam com um Estado que é o "[...] comitê executivo das classes dominantes [...]", não há como prática e teoria não manterem uma relação de dicotomia. Na prática, dirão os graduandos, "[...] a teoria é outra $[\ldots]$ ".

Não se trata de duas diferentes concepções teóricas a distinguir o campo da prática do campo da teoria, mas sim de uma mesma concepção que é incapaz de articular uma prática consequente a partir de uma crítica igualmente consequente do capitalismo. Como a concepção democrática que predomina entre nós é incapaz de compreender a essência do mundo, os princípios práticos que dela decorrem são, perdoem o jogo de palavras, impraticáveis. E a prática profissional cotidiana não pode servir de terreno de prova de tal concepção democrática porque, há muito, a concepção democrática não mais retira dos impasses históricos da profissão elementos para sua crítica e autocrítica.

A concepção democrática, que sempre foi politicista e que degenerou para ser eleitoreira, não pode iluminar teoricamente a prática: ela não é capaz de pensar a realidade sobre a qual a prática incide. Termina por colocar os assistentes sociais em tal desvantagem frente aos poderes constituídos que pouco mais podemos fazer do que correr com o pires na mão em busca de algum recurso para re- 
alizar alguma política pública. Ou, então, administrar o gigantesco programa de esmola federal, "[...] política de governo e projeto de poder [...]” (FREI BETTO) que é o Bolsa Família e os programas congêneres. A prática, nesse contexto, limita-se a atuar administrativamente (Marx, 2010) - e que referencial teórico crítico, mobilizador de nossas potências emancipatórias, pode tal prática encontrar na concepção democrática?

Conceber a revolução como a democratização do Estado pela ação dos trabalhadores não pode oferecer à profissão mais do que já o fez. É uma concepção da sociedade e do papel dos assistentes sociais que não pode articular teoria e prática porque vela aspectos decisivos da essência do mundo em que vivemos. Precisamos, hoje, de uma concepção comunista e, para tanto, a recuperação do proletariado como a classe revolucionária é, por excelência, um passo fundamental, ainda que certamente não suficiente.

Pode ser que a crise que amadurece nos ofereça melhores condições para o confronto, mesmo da profissão, com o Estado. Se isso ocorrer, o Serviço Social poderá crescer e ganhar em densidade tanto profissional quanto político-histórica, se estiver minimamente preparado. Hoje, essa preparação requer o reconhecimento da derrota histórica do projeto democrático surgido com os movimentos populares, requer a crítica dos seus fundamentos teóricos e ideológicos. Precisamos passar do horizonte ideológico "dos trabalhadores" em geral para o horizonte ideológico do proletariado, assim como nos converter de democratas mais ou menos radicais em comunistas: em poucas palavras, esse será o desafio que a profissão enfrentará nos próximos anos, principalmente se a história for minimamente generosa com a humanidade.

\section{REFERÊNCIAS}

ALMEIDA MELLO, L. I. Golbery revisitado: da abertura controlada à democracia controlada. In: MOISES, J. A. e GUILHON ALBURQUERQUE, J. A. (Orgs.). Dilemas da consolidação democrática. São Paulo: Paz e Terra, 1989. p. 199-222. 
CHASIN, J. A "politização" da totalidade: oposição e discurso econômico. Revista Temas de Ciências Humanas, São Paulo, 1977, p. 23-34.

- O Integralismo de Plínio Salgado. São Paulo: Ciências Humanas, 1978.

. Democracia política e emancipação humana. Revista Ensaio, São Paulo, n. 13, p. 11-26, 1984.

. A sucessão na crise e a crise na esquerda. Revista Ensaio, São Paulo, n. 17/18, p. 7-34, 1989.

CLAUDIN, F. La crisis del movimiento comunista. Paris: Ruedo Ibérico, 1970. [Em especial o capítulo "La crisis teorica”. Há uma tradução brasileira por José Paulo Netto, pela Editora Global, infelizmente hoje esgotada e difícil de ser encontrada mesmo em sebos.]

ENGELS, F. A origem da família, da propriedade privada e do Estado. São Paulo: Expressão Popular, 2010.

FREIRE, A.; ALMADA, I.; PONCE, J. A. de G. Tiradentes, um presídio da ditadura. São Paulo: Scipione Cultural, 1997.

IANNI, O. O colapso do populismo no Brasil. São Paulo: Civilização Brasileira, 1994.

LESSA, S. A emancipação humana e a defesa dos direitos. Revista Serviço Social e Sociedade, São Paulo, v. 90, p. 35-56, $2007 \mathrm{~b}$.

- Crítica ao Praticismo Revolucionário. Revista Praxis, Belo Horizonte, n. 4, p. 35-64, 1995.

. História e ontologia: a questão do trabalho. Revista Crítica Marxista, Rio de Janeiro, n. 20, p. 70-89, 2005.

. Comunismo, do que se trata? In: GALVÃO, A. et al. (Orgs.). Marxismo e o socialismo no século XXI. São Paulo: Xamã, 2005b. p. 197-210. 
- Trabalho e proletariado no capitalismo contemporâneo. São Paulo: Cortez, 2007.

. Serviço Social e Trabalho: porque o Serviço Social não é trabalho. Maceió: Edufal, 2007a.

LUKÁCS, G. Per una ontologia dell'essere sociale. Roma: Rinuti, 1976-1981. 2v.

MARX, K.; ENGELS, F. Manifesto do Partido Comunista. São Paulo: Expressão Popular, 2005.

Marx, K. Crítica do programa de Gotha. In: MARX, K.; ENGELS, F. Critica dos programas socialistas de Gotha e Effurt. Porto: [s.n], 1974. p. 8-16.

. Salário, preço e lucro. São Paulo: Edições Sociais, 1977. [Textos 3].

. O Capital. São Paulo: Abril Cultural, 1983-1985. Tomos I e II (v.1).

. Para a questão judaica. São Paulo: Expressão Popular, 2009.

. Teses sobre Feuerbach. In: MARX, K. ENGELS, F. A Ideologia alemã. São Paulo: Ed. Expressão Popular, 2009a.

. Glosas Críticas marginais ao artigo "O rei da Prússia e a reforma social" de um prussiano. (Introdução de Ivo Tonet). São Paulo: Expressão Popular, 2010.

MÉSZÁROS, I. Para além do capital. São Paulo: Boitempo, 2002.

NETTO, J. P. Ditadura e Serviço Social. São Paulo: Cortez, 1990.

SADER, E. Quando novos personagens entram em cena. São Paulo: Paz e Terra, 1995.

TONET, I. Liberdade, igualdade e fraternidade: de 1789 a 1989. Revista Ensaio, São Paulo, n. 17/18, p. 89-104, 1989.

. Liberdade ou democracia? Maceió: Edufal, 1999.

. A questão do socialismo. Curitiba: HDD Livros, 2002. 
. Educação, cidadania e emancipação humana. R. G. do Sul: Unijuí, 2005.

. Os descaminhos da esquerda: da centralidade do trabalho à centralidade da política. São Paulo: Alfa-ômega, 2009.

TONET, I; LESSA, S. Introdução à filosofia de Marx. São Paulo: Expressão Popular, 2008. 